\title{
Method for holistic wind turbine drivetrain comparison exemplarily applied to geared and direct drive systems
}

\author{
Freia Harzendorf ${ }^{1} \cdot$ Ralf Schelenz ${ }^{1} \cdot$ Georg Jacobs ${ }^{1}$ \\ Received: 1 December 2020 / Accepted: 20 May 2021 / Published online: 7 December 2021 \\ (c) The Author(s) 2021
}

\begin{abstract}
The drivetrain as an important part of wind turbines needs to be improved in order to deal with today's high development and cost pressure. One important step towards enhanced drivetrains is to identify the most suitable concept for a targeted onshore application in an early design stage. With this purpose, a holistic lifecycle system evaluation approach relying on minimum input information is presented. In order to identify a dominant solution, an additive target system is defined taking cost, ecological sustainability, and supplied energy into account. This multi-criteria decision is aggregated by defining a macrosocial evaluation criterion: "drivetrain specific energy supply effort". A physics- and empirically-based model is developed to quantify the targets for different onshore drivetrain concepts. The validity of the model results is shown by a comparison to meta-analysis findings. Being utilized on a drivetrain concept comparison between geared and direct drive the approach's value is showcased. Both concepts score on a comparable level slightly differing in weak and strong wind regimes. An exemplary trade-off between investment- and operational effort shows, that for both concepts the investment effort is higher than the operational. The comparison furthermore shows how robust decision support can be provided by parameter variation and finally it stresses, that the decision maker's preferences need to be incorporated in the decision. Concluding, this analysis shows that physics- and empirically-based model approaches enable holistic wind turbine drivetrain concept comparisons in an early design stage.
\end{abstract}

Freia Harzendorf

freia.harzendorf@rwth-aachen.de

1 Center for Wind Power Drives, RWTH Aachen University,

Campus-Boulevard 61, 52074 Aachen, Germany 


\section{Methode zur ganzheitlichen Bewertung von Windenergieanlagen-Antriebssträngen exemplarische Anwendung auf den Vergleich von Konzepten mit und ohne Getriebe}

\section{Zusammenfassung}

Um adäquat auf den heutigen Entwicklungs- und Kostendruck in der Windbranche zu reagieren, sollte eine Verbesserung des Windenergieanlagen-Antriebsstrangs im Fokus stehen. Wichtig ist es hierbei in einer frühen Produktentwicklungsphase ein optimal auf den Standort abgestimmtes Antriebsstrangkonzept zu identifizieren. Ziel dieser Publikation ist die Vorstellung eines ganzheitlichen, den gesamten Produktlebenszyklus betrachtenden, Bewertungsansatz für Windenergieanlagen-Antriebsstränge, welcher ein Minimum an Eingangsdaten benötigt. Um das jeweils überlegene Konzept zu identifizieren, wird ein additives Zielsystem definiert welches Kosten, ökologische Nachhaltigkeit und die bereitgestellte Energiemenge berücksichtigt. Dieses multikriterielle Zielsystem wird zu dem makro-sozialen Bewertungskriterium „Antriebstrangkonzeptspezifische Energiebereitstellungskosten“ aggregiert. Zur Bewertung bzw. Quantifizierung der Zielerfüllung verschiedener Onshore Konzepte werden physikalische- und empirische Modelle entwickelt. Deren Validität wird durch den Vergleich zu Ergebnissen aus einer Metaanalyse nachgewiesen. Durch die Anwendung auf den Vergleich zwischen einem Antriebsstrangkonzept mit und einem ohne Getriebe kann der Mehrwert dieses Ansatzes dargestellt werden. Beide Antriebsstrangkonzepte schneiden im Vergleich ähnlich gut ab, unterscheiden sie sich jedoch in der Anwendung auf Starkwind- oder Schwachwindstandorte. Die Betrachtung eines exemplarischen Trade-offs zwischen Investitions- und Betriebskosten zeigt, dass für beide Konzepte die Investitionskosten schwerer ins Gewicht fallen. Durch den Vergleich kann zudem gezeigt werden, wie durch eine Parametervariation die Robustheit der Ergebnisse analysiert werden kann. Zudem zeigt die Anwendung, dass die entscheidungspersonenspezifischen Präferenzen in der Entscheidung berücksichtigt werden müssen. Zusammenfassend ermöglicht der vorgestellte Bewertungsansatz, basierend auf physikalischen und empirischen Modellen, die Durchführung von robusten und ganzheitlichen Windenergieanlagen Antriebsstrangkonzept-Vergleichen in einer frühen Produktentwicklungsphase.

\section{Introduction}

Wind and solar power play an important role in realizing the German energy transition [1]. Facing the decarbonization of the mobility, industry, heat and electricity sector the needed renewable electricity amount will more than double between today and 2050 in Germany [2]. If Power-to-X and other storage technologies are included to strengthen the energy system, there is an even higher demand for cheaper renewable electricity, due to the losses in conversion processes [3]. Therefore, high investment in wind and solar capacity is definitely required. Nevertheless, reduced or foreseeable expiring feed-in remuneration schemes diminish the attractiveness of investments into wind power projects. This puts the whole wind industry under cost and development pressure. The average bid awarded in the German onshore tendering in December 2020 was $5.91 \mathrm{Ct} / \mathrm{kWh}$ [4]. This can be used as an indicator for the levelized cost of energy (LCOE) for electricity provided by onshore wind power. The average revenue source on the electricity market, the day-ahead price, was on average at $2.9 \mathrm{Ct} / \mathrm{kWh}$ in the respective year [5]. In order to overcome this huge discrepancy, between future revenue potential and energy supply expenses, technological development is needed.

The wind turbine drivetrain, as the sum of the energy converting components between hub and transformer, has a significant influence on the turbine's properties and costs. $34 \%$ of the turbine's investment cost can be accounted for the nacelle and its components [6]. In this consideration nacelle includes the housing and auxiliary equipment on top of the tower in addition to the drivetrain. Over $80 \%$ of the unplanned failures of a turbine can be traced back to nacelle components [7]. In the partially rated range over $15 \%$ of losses can have their origin in the energy conversion within the drivetrain [8]. 10-20\% of the overall turbine $\mathrm{CO}_{2}$-emission can be traced back to the drivetrain [9]. Concluding a holistic evaluation of wind turbine drivetrain concepts over their entire lifecycle should be the logical response to the prevalent development and cost pressure.

Innovation in general and in the wind turbine's drivetrain is mainly motivated by the goal to have a better product. In this context better product is defined as a product that is improved in any reasonable regards(s). Decisions made in the early design stage have the highest influence on the final product [10]. However, the early design stage, when concept and design decisions are made, is characterized by a high degree of complexity, uncertainty, and information deficits. Decisions have to be made about products which will be introduced into the market in two to five years under changed market conditions. Moreover, cost due to changes in the product design disproportionately increase with the maturity level of a product [10]. In order to avoid cost drivers in the later stages of the product lifecycle, the drivetrain should be analyzed holistically over its entire lifetime in an early design stage. 
In today's market, mainly three different conventional drivetrain concepts can be distinguished: geared also known as high-speed, direct drive also known as low speed and finally mid speed concepts. Underlying are different technical ideas about the best way to carry and convert mechanical into electrical energy leading to distinct characteristics in the different life cycle stages. High-speed concepts are based on the idea, that a transformation of the rotational speed and torque with the help of a gearbox makes it possible to use smaller generators for the mechanical-electrical transformation. It moreover enables to make use of an asynchronous generator concept (doubly fed induction generator (DFIG)), which just needs a partially rated converter. Due to the less complex and lighter generator and converter the drivetrain mass is comparably low. Nevertheless, using the component gearbox adds more energy losses to the system and a source of failure due to high rotating parts. Whereas the direct drive concept waives of the component gearbox and instead needs enlarged synchronous generators, which are either permanent magnet or electrically excited. They rely on a fully rated converter. Getting rid of the component gearbox can increase the system's energy conversion efficiency and might increase its reliability. Nevertheless, lower input speed and higher input torque will lead to more pole pairs and a stiffer generator structure needed. This often results in a heavier drivetrain system, which needs more material and therefore more $\mathrm{CO}_{2}$-emissions are emitted in this lifecycle stage. Depending on the generator concept a dependency of the availability and price for rare earth is possible. In the following, high-speed concepts are referred to as geared and low speed concepts are referred to as direct drive. Mid speed concepts available in the market adopt aspects of both aforementioned concepts. They use a gearbox to increase the rotational speed but have a lower ratio than the high-speed concepts. Therefore, they mainly use a permanent magnet synchronous generator (PMSG) and need a fully rated converter. Reducing the generator weight and complexity by increasing the rotational generator input speed while having a small gearbox might have the potential to result in a lighter system compared to geared and direct drive concepts. Still efficiency losses due to the gearbox and the possible dependency on rare earth material exists. Concluding all concepts have specific advantages and disadvantages in different lifecycle stages, by looking at them individually it is not possible to identify the best system.

Casting a glance into currently available literature shows, that some wind turbine drivetrain concept comparisons have already been conducted. Fig 1 illustrates the used evaluation criteria as well as the best performing concept in the respective comparison. It is visible that a multitude of different criteria is used. Nevertheless, there is no approach yet available including a holistic set of criteria. This means considering the entire lifecycle as well as influences of and interdependencies between different drivetrain components. Some authors already marked this critically $[11,12]$. Moreover, the comparisons are highly dependent from underlying assumptions the authors make. In some publications these assumptions are not transparent, not understandable or not generalizable. Furthermore, underlying uncertainties vary with the evaluated drivetrain concept [13]. These can be reasons for diverging comparison results while comparing with regards to the same evaluation criteria. This becomes extremely visible when analyzing the operational phase. Some sources recommend geared drivetrains [14-16] while others suggest using direct drive concepts $[13,17]$ for the same application. Concluding literature approaches are not yet able to sufficiently support the early stage drivetrain concept decision.

To fill this gap the present study aims to consider the effects the drivetrain decision can have on the entire turbine's lifecycle in one holistic approach with minimal input information. It targets the quantification of trade-offs of different drivetrain concepts in different lifecycle phases. In order to evaluate and compare presently available drivetrain
Fig. 1 State of the art in literature. $D F I G$ doubly fed induction generator, three stage gearbox and partially rated converter, $P M S G$ permanent magnet synchronous generator as a direct drive with a fully rated converter, Mid speed PMSG permanent magnet synchronous generator, two stage gearbox and fully rated converter, 3-pt. susp. threepoint suspension system, Susp. suspension system

\begin{tabular}{|c|c|c|c|c|c|c|c|}
\hline & \multicolumn{7}{|c|}{ Evaluation criteria } \\
\hline Source & $\begin{array}{l}\text { Investment } \\
\text { cost }\end{array}$ & $\begin{array}{l}\text { Operational } \\
\text { cost }\end{array}$ & $\begin{array}{l}\text { Avail- } \\
\text { ability }\end{array}$ & $\begin{array}{l}\text { Relia- } \\
\text { bility }\end{array}$ & $\begin{array}{l}\text { Effi- } \\
\text { ciency }\end{array}$ & $\begin{array}{l}\text { Drivetrain } \\
\text { mass }\end{array}$ & $\begin{array}{l}\text { Sustain- } \\
\text { ability }\end{array}$ \\
\hline [11] & DFIG & & & & PMSG & & \\
\hline [14] & & DFIG & & & & & \\
\hline [21] & & & \multicolumn{2}{|c|}{ PMSG } & & & \\
\hline [15] & & & & DFIG & & & \\
\hline [22] & \multicolumn{5}{|c|}{ PMSG (offshore) } & & \\
\hline [22] & & & \multicolumn{2}{|c|}{ PMSG } & & & \\
\hline [13] & 3-pt. susp. & & & & & & \\
\hline [12] & \multicolumn{5}{|c|}{ Mid speed PMSG } & & \\
\hline [23] & & & \multicolumn{2}{|c|}{ DFIG } & & & \\
\hline [24] & & & & & & Susp. & \\
\hline [25] & & & & & & & $\overline{\text { DFIG }}$ \\
\hline [26] & & & mid & I PMSG & & & \\
\hline
\end{tabular}


configurations, a physics- and empirically-based model is presented which can be applied in an early drivetrain concept decision [18-20]. A great emphasis has been put on the wide parameterization of the model in order to allow a broad application in an early design stage despite of the lack of data. The default model parameterization is based on literature data. But it can be easily customized with industrial data from an wind turbine original equipment manufacturer (OEM), which will improve the result's accuracy. The model is built up on three pillars:

- A physics-based lifecycle costing approach

- An ecological sustainability approach

- An annual energy production approach

The publication is structured as follows. The overall model approach and the used sub-models are presented in Chap. 2. In a case study, the developed approach is applied on the comparison between geared and direct drive concepts. The results are presented in Chap. 3. Finally, Chap. 4 concludes and gives an outlook.

\section{Model}

The overall goal in the design stage of a drivetrain is to find the most suitable solution. Rephrased, the design engineers are looking for a system solution which is dominant against the alternatives when taking the entire lifecycle of the system and possible changes in external influencing factors into account. In order to be able to quantify this dominance, an additive target system is defined using a bottomup approach. The target system is compiled by the following three targets in order to make it fundamental, complete, redundancy-free and unbiased:

- Minimal lifecycle cost,

- Maximal sustainability over the lifecycle and

- Maximal energy supply over the lifecycle.

For solving this multi-criteria weighting problem, the authors recommend using the trade-off approach for identifying the decision-makers' specific weighting between the three targets. Practical advice is presented in von Nitzsch et al. 2014 [27]. This additive target system has the advantage, that customized preferences for individual OEM application are easily implemented.

Within this paper the solution mostly complying with a macrosocial perspective is of interest as it is generalizable and this way of interest for most readers. From a macrosocial perspective, a system solution complying with the German energy policy target triangle (reliable, cost effective and environmentally friendly electricity supply) is in favor [28]. Therefore, a comparative figure, "drivetrain specific energy supply effort" (DSE), is defined in analogy to the LCOE metric for the drivetrain, please compare Eq. 1 [29]:

$L C O E=\frac{I_{0}+\sum_{t=1}^{20} \frac{O_{t}}{(1+i)^{t}}+\frac{I_{21}}{(1+i)^{21}}}{\sum_{t=1}^{20} \frac{E_{t}}{(1+i)^{t}}}$

$I_{0}$ accounts for the initial investment, which means cost for material, manufacturing, transport and installation of the drivetrain. $O_{t}$ includes cost arising during the operational phase. They are taken into account in the time of origin $t$. End of life cost are considered by $I_{21}$, as it is assumed that the drivetrain is deconstructed after 20 years of operation. The discount rate is depicted by $i . E_{t}$ accounts for the electricity supply in the respective year $t$ of the entire turbine. The lower LCOE the less expensive a drivetrain can supply electricity.

In contrast to LCOE, the metric DSE internalizes external cost due to $\mathrm{CO}_{2}$-emissions emitted during the product's lifecycle. Emissions are monetarily taken into account by using the price of $\mathrm{CO}_{2}$-certificates $(25.15 € / \mathrm{t}$ in May 2020 [30]). Furthermore, only the lifecycle of the drivetrain is considered with cost and emission in the metric DSE. The amount of electricity provided is, however, related to the entire turbine. Similar to the LCOE, the time of cost-, emission- or electricity-emergence defines when these quantities are taken into account, please compare Eq. 2:

$D S E=\frac{I_{0(e+c)}+\sum_{t=1}^{20} \frac{O_{t(e+c)}}{(1+i)^{t}}+\frac{I_{21(e+c)}}{(1+i)^{21}}}{\sum_{t=1}^{20} \frac{E_{t}}{(1+i)^{t}}}$

$I_{0(e+c)}$ accounts for the initial investment, which means cost and emission for material, manufacturing, transport and installation of the drivetrain components. $O_{t(e+c)}$ includes cost arising and emission emitted during the operational phase. They are taken into account in the time of origin $t$. End of life efforts (cost and emission) are considered by $I_{21(e+c)}$, as it is assumed that the drivetrain is deconstructed after 20 years of operation. The discount rate is depicted by $i . E_{t}$ accounts for the electricity supply in the respective year $t$. The lower DSE is the better a concept fulfills the set requirements.

In order to quantify the different concepts' target manifestation physics and empirically-based models are developed. The model's goal is to quantify the influence the technical drivetrain concept choice has on the different lifecycle stages in terms of cost, supplied energy and $\mathrm{CO}_{2}$-emissions. Fig. 2 gives an overview about the model structure. The entire lifecycle of an onshore wind turbine drivetrain is evaluated by the model. For every life stage, a sub-model has been developed. Different drivetrain components are differentiated based on their functionality. A modular approach is used. The sub-models are implemented in a way that concept (un)specific parameters (like material prices, failure 
rates, specific emissions e.g.) can be easily adjusted if updated information or knowledge is available. Model input are general requirements for the application of the drivetrain which are usually available in an early design stage, e.g. rated power and rotor diameter. Model output is a quantification of the target system. It is implemented in Matlab. In the following, the manifestation of the used sub-models and the main underlying ideas and assumptions are briefly described.

\subsection{Rough designing of components}

The rough designing of the mechanical drivetrain components (suspension system, gearbox and mainframe) is mainly based on approaches developed by the National Renewable Energy Laboratory (NREL) based in the United States of America [31, 32]. Considering the main loadings of the component, its geometry and mass are estimated based on physical and empirical relationships. This way the approach is scalable, and the impact the design choice for one component has on the rest of the drivetrain system can be captured. Generator and converter mass are estimated based on regression functions from [32].

\subsection{Material effort estimation}

Based on the estimated component mass, the material effort, defined as the semi-finished product, is estimated in this sub-model. Average component specific material distributions are derived from available literature sources [33-42]. A two-step approach is then used to estimate the semi-finished product effort. First, literature sources about raw material prices are compiled. With the help of the GENESIS database of the German federal statistical office, the processing effort from raw material to semi-finished product in terms of cost is estimated [43]. For emissions, literature provides material specific emissions which are used [44-49].

\subsection{Manufacturing effort estimation}

The manufacturing cost estimation is based on a generative, bottom-up approach. As a first step, the components manufacturing is split up into its most important process steps. The machine-hour-rate calculation then allows to estimate the manufacturing effort for these defined process steps [50]. For estimating the needed machine runtime, components geometry and average process parameters, derived from literature, best practices and expert interviews, are used. A more detailed presentation is available in [36]. For the emission estimation in this lifecycle phase, literature provides a manufacturing surcharge for process energy which is used in this approach [51].

\subsection{Transportation effort estimation}

The transportation effort estimation approach is based on interviews with practitioners [52, 53]. Component mass and geometry are modelled as factors influencing rent of transport vehicles, needed equipment, and wages. Incidental transportation cost cannot be quantified in an early design stage; therefore, a risk classification is used in this approach. This way it is possible to indicate if a certain drivetrain design might lead to high incidental transportation effort in an early design stage. Emissions due to the use of fuel for the transport vehicle are considered for the transportation phase.

\subsection{Installation effort estimation}

In this approach installation effort is modelled as effort for the needed equipment for lifting the drivetrain on the turbine tower (crane). Based on hook height and lifting load an industrially available crane is chosen from a database [54]. The equipment cost is composed by a fixed and a variable part. Fixed are the expenses for journey, installation, disassembly and departure of the crane. Variable is the duration of the installation, which influences the renting fee as well as wages. Emissions due to fuel used for the identified crane are considered for the entire installation phase.

\subsection{Operational effort estimation}

Planned maintenance is considered by semi-annual inspections whose durations are influenced by the constituting components of the drivetrain concept. For example, for concepts relying on a complex lubrication system, additional treatment is considered. From a sustainability point of view emissions due to using a vehicle for planned maintenance are considered.

For modelling the unplanned operational drivetrain behavior, a statistical approach based on Monte Carlo simulation is developed. The most relevant influencing factors are considered by modelling failure rate, downtime, failure severity and duration of repair and replacement as uncertain factors. Their manifestation is based on literature sources. This way it is possible to estimate the labor, material, and equipment expenses which are caused by unplanned failures during the operational phase. A more detailed presentation and application of this sub-model is available in [20]. Reason for emissions, arising from unplanned operational measures, are owing to fuel for vehicles, material and manufacturing of spare parts and crane fuel consumption if needed. 
Table 1 Literature sources for comparative figures in the meta-analysis

\begin{tabular}{lllll}
\hline & Drivetrain investment cost & Drivetrain operational cost & $\mathrm{CO}_{2}$-lifecycle-emission & Levelized cost of energy \\
\hline Sources & {$[56-61]$} & {$[62-69]$} & {$[9,70-73]$} & {$[62-67,74-90]$}
\end{tabular}

Table 2 Drivetrain concept characteristics

\begin{tabular}{llllll}
\hline Concept & Suspension system & Gearbox type & Generator type & Converter & Market share [\%] [94] \\
\hline 3P-3G-DFIG-PC & 4-point & 3-stage & DFIG & Partially rated & 40 \\
MB-PMSG-FC & Moment & - & PMSG & Fully rated & 10 \\
\hline
\end{tabular}

\subsection{End of life effort estimation}

For disassembly, the described installation sub-model is used as it is assumed that the same crane will be utilized. Transportation effort is estimated by the presented transportation effort estimation. Based on literature recycling of the component's material is considered. Emissions during disassembly and transportation are considered similar to the way described in the transportation and installation effort estimation. Emissions saved due to recycling of metal, rare earth and lubricant emissions are credited in the overall balance.

\subsection{Efficiency estimation}

For estimating the concept's efficiency, component design specific power curves from literature are used [8, 55]. They are normalized to the rated power and therefore scalable in the model's approach.

\section{Model validation}

In order to validate sub-model results with this current literature based parameterization, the method of meta-analysis is utilized. With the help of this secondary analysis technique, empirical study results are aggregated to intervals of comparative figures manifestation. By comparing the model results to the comparative figures from literature, an indication about the model's validity becomes possible. Due to the poor availability of data in literature, all obtainable sources are used which are listed in Table 1 . The validation is conducted for two prominent drivetrain concept. Table 2 gives an overview about the chosen concepts' characteristics.

The validation results are presented in a boxplot with four comparative figures (c.f. Fig. 3). The category literature I indicates the extreme values (min and max) from literature whereas literature II represents the mean and standard deviation. The results for the concepts introduced in Table 2 are based on a parameter study with a rotor diameter varying between 80 to $160 \mathrm{~m}$ combined with a rated power varying between 2 to $4 \mathrm{MW}$, respectively. This represents a historic turbine configuration. The reference site from German renewable energy act is used [91]. Implemented with an average wind speed of $6.45 \mathrm{~m} / \mathrm{s}$ at 100 meter and a Weibull form factor of 2.1396 .

For calculating the drivetrain's share on turbine investment cost, the model results are related to a literature average value for turbine investment of $1,010 € / \mathrm{kW}$ [92]. Turbines sold for 2020/2021 aim at prices around $736 € / \mathrm{kW}$,
Fig. 2 Overview of the model structure

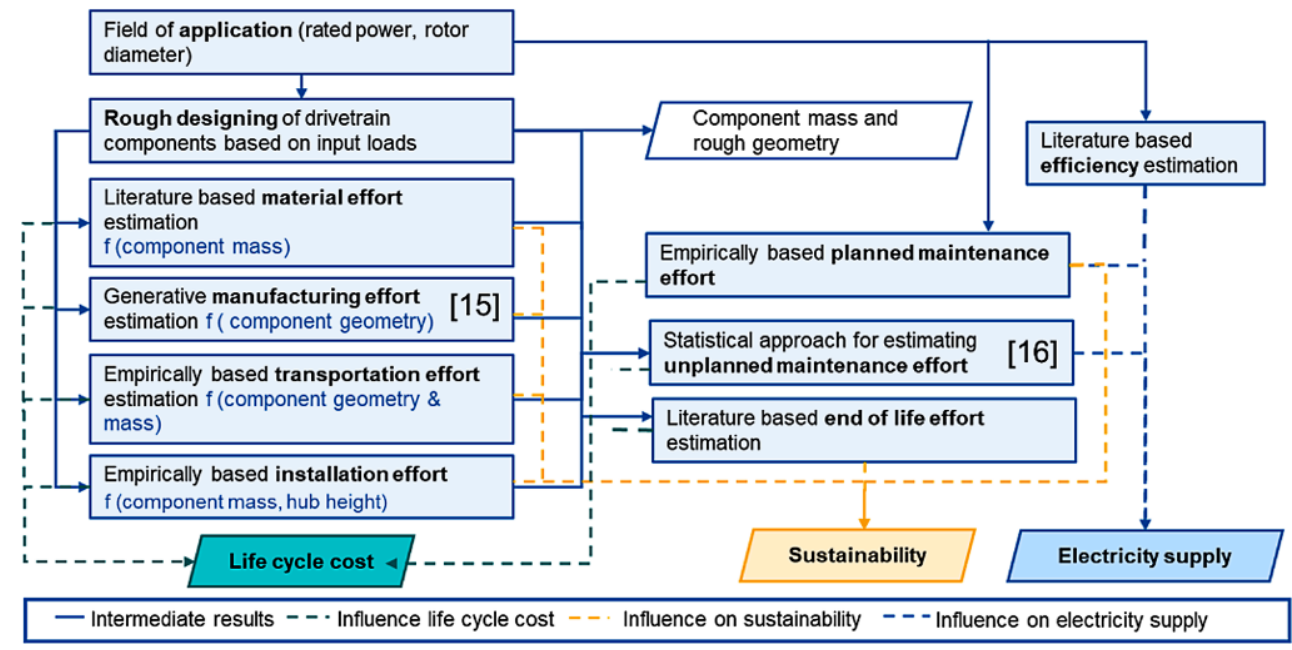


Fig. 3 Model results compared to meta-analysis findings
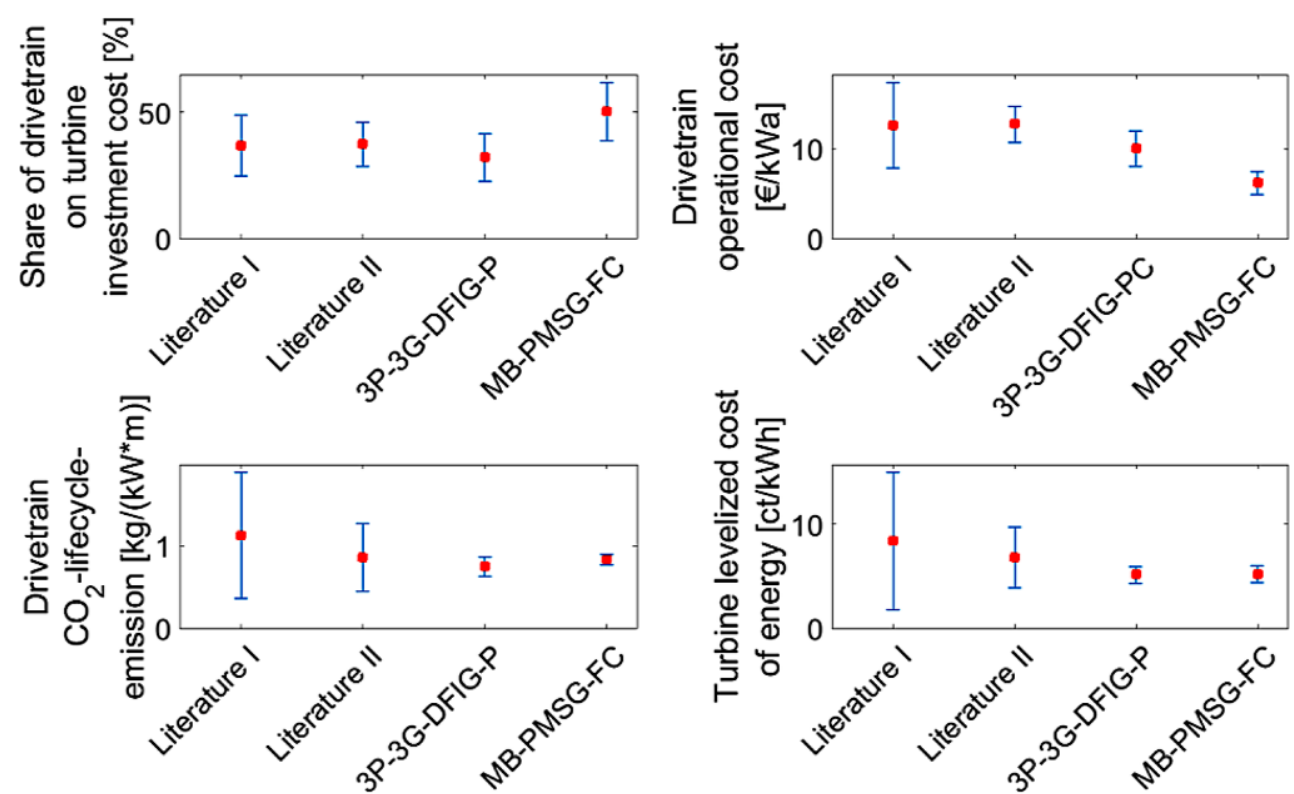

reasons for this decrease are lower margins in the entire supply chain and improved design [93]. Nevertheless, the historic value is chosen here in order to align with the other meta study sources. Looking at Fig. 3 the mean values of the considered concepts are within the literature bandwidth for the investment cost share. As the sources used in the meta-analysis are all of age, the authors assume that mainly geared concepts are considered here. Nevertheless, the model reflects the fact that the direct drive concept MBPMSG-FC leads to a higher share of the drivetrain on the overall turbine investment cost, which is known in literature [11, 22]. Drivetrain operational cost is slightly underestimated for both concepts. Though, the mean result of both concepts is within the "literature I" boundaries. The qualitative comparison between the two concepts in terms of operational cost reflects common knowledge in literature e.g. [13]. Drivetrain related $\mathrm{CO}_{2}$-emissions over the lifecycle are calculated based on sources estimating the en-

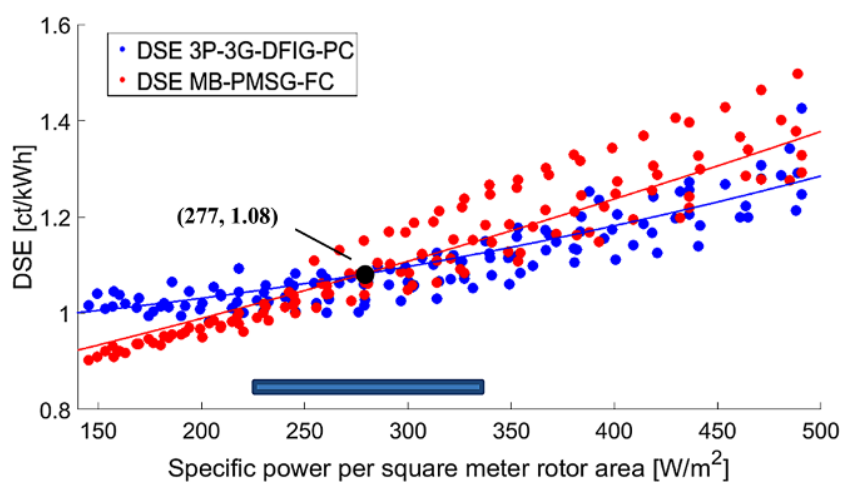

Fig. 4 Concept comparison with regards to DSE tire turbines lifetime emissions. It is assumed, that 10-20\% of these emissions can be traced back to the drivetrain [9, 72]. Model results for both concepts are within the broad literature boundaries. Furthermore, literature confirms the differences in $\mathrm{CO}_{2}$-lifecycle-emmisions between the concepts visible in Fig. 3 [25]. The levelized cost of energy for the two concepts are both within the meta-analysis boundaries. In general all model results are above $5 \mathrm{ct} / \mathrm{kWh}$, which vaguely corresponds to the auction results in Germany [4].

This way the model results of this literature based parameterization in general seem plausible as the orders of magnitude for the comparative figures are met and advantages and disadvantages of the different concepts are represented in the model results. Concluding, this analysis shows that with the help of physics- and empirically-based model approaches, viable wind turbine drivetrain concept comparisons are possible from a holistic point of view in an early design stage.

\section{Case study: Comparison of geared and direct drive wind turbine drivetrain concepts}

Within the following chapter the presented approaches applicability for supporting drivetrain design decisions is showcased. Therefore, a parameter study for today's and near future's turbine configuration is conducted for the two drivetrain concepts 3P-3G-DFIG-PC and MB-PMSG-FC (c.f. Table 2). The rotor diameter is varied between 80 to $200 \mathrm{~m}$ in $10 \mathrm{~m}$ steps. The turbines hub height is varied in accordance with changes in the rotor diameter (hub height $=40 \mathrm{~m}+1 / 2$ rotor diameter). Whereas the rated power 
Fig. 5 Concept comparison with regards to DSE while varying rotor diameter and rated power

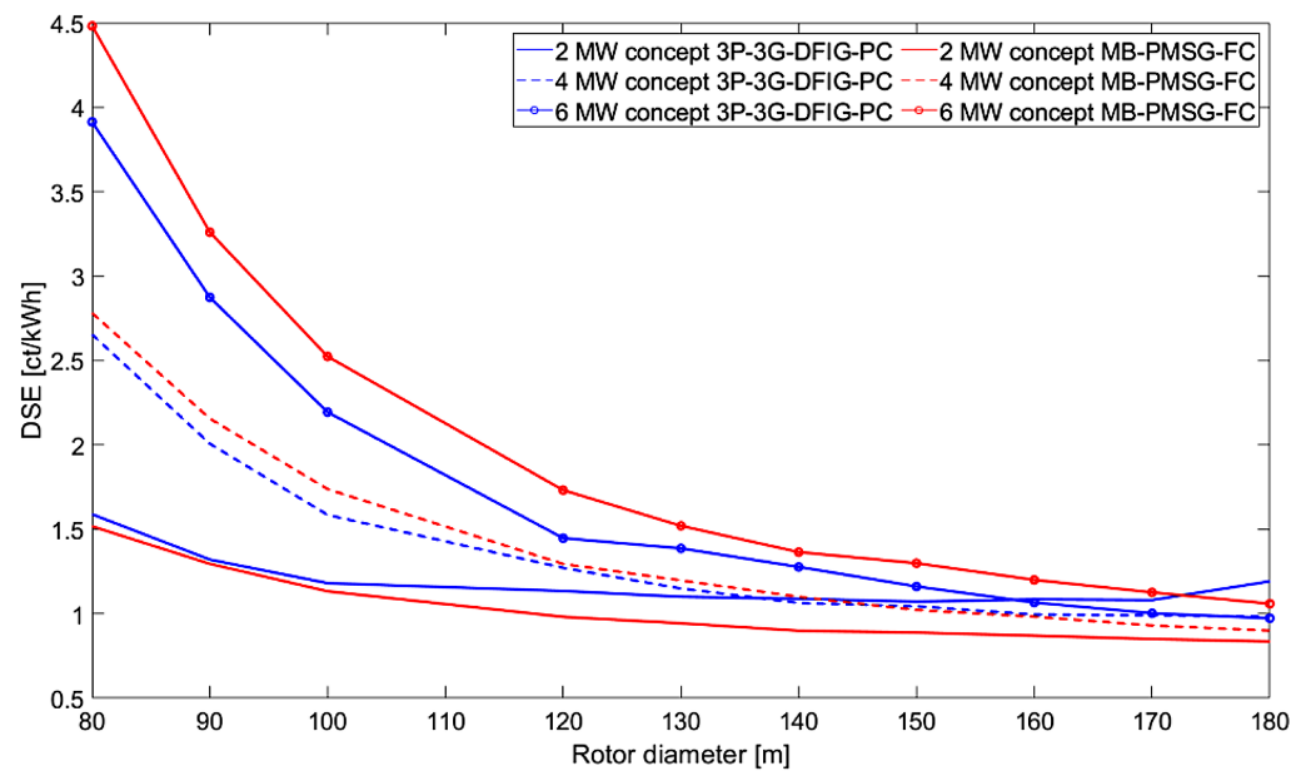

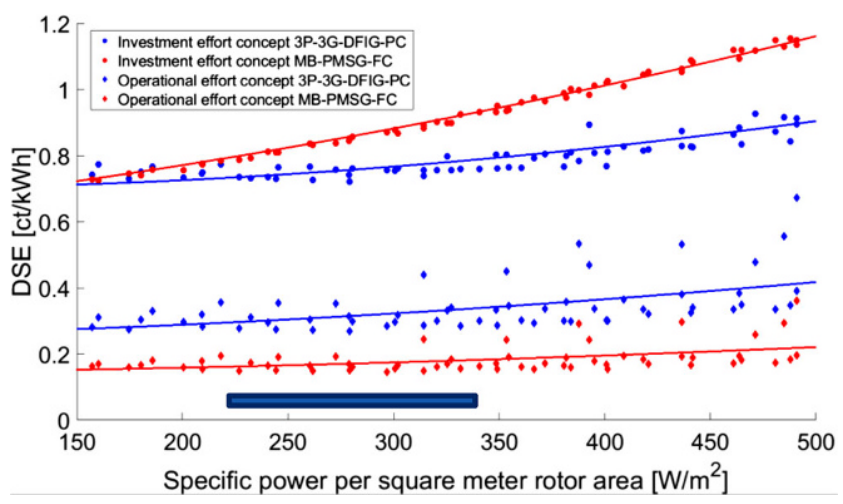

Fig. 6 Concept comparison with regards to the investment and operational phase

is modified in the interval of 2 to $7 \mathrm{MW}$ in $250 \mathrm{~kW}$ steps. The same site characteristics as for the meta study are assumed.

In Fig. 4 the conducted comparison is depicted. The $\mathrm{x}$-axis represents a comparative value describing the requirements with respect to rated power and rotor diameter. The blue bar just above the $\mathrm{x}$-axis indicates the characteristics of currently available turbines on the market varying between 229 and $340 \frac{\mathrm{W}}{\mathrm{m}^{2}}$ [95-98]. These turbines are going to be installed in the coming years. On the y-axis, the derived comparative value DSE (c.f. Equation 2) for identifying the favorable system solution from a macrosocial perspective in the model framework is plotted.

Focusing on the near future turbines field of application both concepts scatter on a comparable level. Therefore, no concept seems clearly dominant about the other. Several rotor diameter and rated power combinations can result in the same specific power per square meter rotor area. It is site

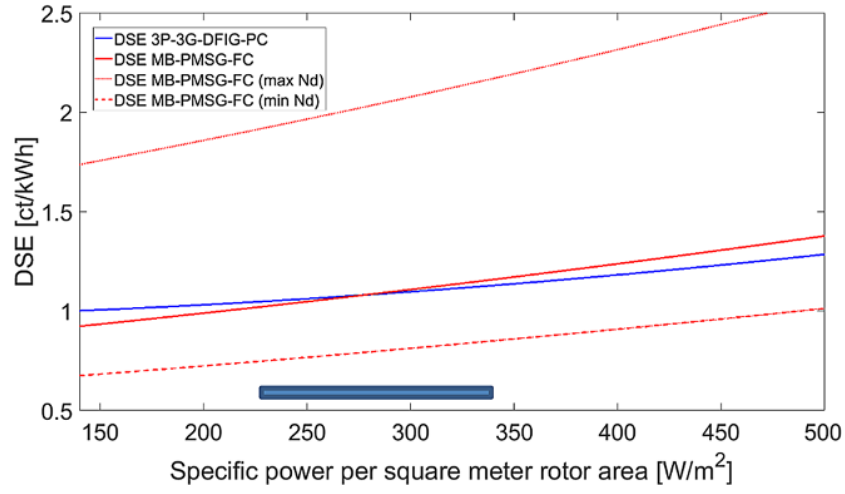

Fig. 7 Concept comparison with historic extreme neodymium material prices

dependent if a bigger rotor combined with a higher rated power is superior over a shorter rotor combined with less rated power and the same specific power per square meter rotor area. Using a regression function for both concepts, an intersection at $277 \frac{\mathrm{W}}{\mathrm{m}^{2}}$ is apparent. Though it needs to be taken into account, that individual dots have to be compared for a design decision. This way $277 \frac{\mathrm{W}}{\mathrm{m}^{2}}$ is not a strict line but can be interpreted as an indicator for a change in the concepts favorability. Based on the analysis a slight trend can be derived that drivetrain concept 3P-3G-DFIG$\mathrm{PC}$ might be more suitable for stronger wind applications whereas concept MB-PMSG-FC seems better qualified to be applied in the weak wind regimes for the analyzed site and the underlying assumptions. As indicated in Table 2 both concepts are widely deployed in the market. The above presented result gives an answer to why we nowadays see both concepts in the market from a technological point of view. 


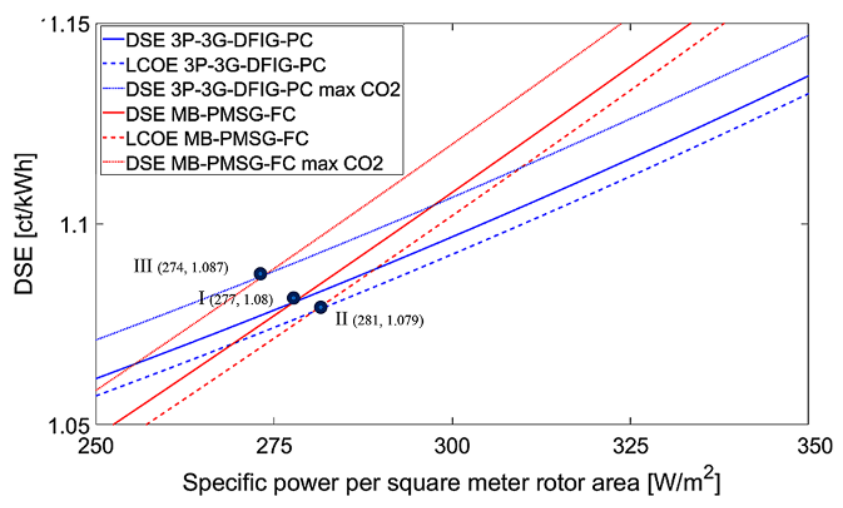

Fig. 8 Concept comparison with regards to DSE, LCOE and changed $\mathrm{CO}_{2}$-certificate price

Fig. 4 allows a concept comparison for different areas of application indicated by the specific power per rotor square meter. Fig. 5 now enables DSE statements about specific rotor diameter and rated power combinations. For the assumed site conditions (rather weak wind regime) it becomes visible, that a rotor diameter above $120 \mathrm{~m}$ is more advantageous for most applications. Thus a larger rotor diameter leads to disproportionate growth in energy supply compared to growth in cost and $\mathrm{CO}_{2}$-emission. Moreover it shows that for lower rated power applications ( $2 \mathrm{MW})$ the direct drive concept has advantages over the entire range of rotor diameters in terms of DSE. Whereas for medium and high rated power $(4 \& 6 \mathrm{MW})$ the geared concept results in the lowest DSW per rotor diameter.

In order to understand what causes this behavior, it is of interest to explore the influence of the different drivetrain lifecycle phases on this score. Fig. 6 therefore allows to analyze the trade-off between investment and operational phase on the overall DSE. End of life is integrated into the operational phase in this figure. For both concepts under investigation the investment phase has a higher impact on the lifecycle DSE than the operational phase. It increases with the specific power per square meter rotor area for both. Nevertheless, the slope for concept MB-PMSG-FC is much steeper, the higher the specific power per square meter rotor area becomes. So, the direct drive concepts result is more sensitive to increased rated power application compared to rotor diameter. For low specific power per square meter, deciding for a direct drive concept can even lead to the lowest impact in the investment phase. The changes in the operational phase due to changed drivetrain application area are relatively comparable. Hence the geared concept 3P-3GDFIG-PC starts at a higher initial point and has a slightly steeper slope. Knowing these relationships, concept specific areas for improvement can be identified.

As stated in the model description, an advantage of this approach is the possibility to incorporate external developments which impact the concepts performance e.g. volatil- ity in raw material prices and this way shortages in their availability. In the following it is shown, how the developed approach can support in this way. Figs. 4, 5 and 6 depict results valid for a specific set of external influencing factors. In order to assess the robustness of a concepts favorability against changes in these external influencing factors, they can be varied and the influence on the results be analyzed. In Fig. 7 this is exemplarily depicted for the historical extreme values of the material price for neodymium, the material used in PMSG because of its permanent magnetic characteristics. The starting price is the neodymium price of today (calendar week 6 in 2021) $116.81 € / \mathrm{kg}$ [99]. It is compared to the ten years minimal material price $25.75 € / \mathrm{kg}$ in January 2010 [100] and the ten years maximal price of $415.11 € / \mathrm{kg}$ in June 2011 [101]. A huge impact on the concepts favorability is visible for the regression functions for each scenario. For an application in a design decision, design engineers need to assess which factor variability they expect for the future and conduct several analysis with changed external influencing factors. This way a more robust decision support can be provided.

Finally, the introduced macrosocial evaluation criteria DSE as a first step to include cost-to-society (including external $\mathrm{CO}_{2}$-cost) is contrasted to the popular metric LCOE in Fig. 8. As DSE incorporates cost for $\mathrm{CO}_{2}$-certificates it is in general higher than LCOE, visible in the plotted regression function in Fig. 8. As distinct drivetrain concepts perform differently in terms of sustainability, the metric choice for conducting the comparison can have an influence on the advice derived from the model results. This in particular becomes apparent when the $\mathrm{CO}_{2}$-certificate price is increased. The lighter colored regression functions in Fig. 8 depicts the model results for an estimation about $\mathrm{CO}_{2}$-certificate price in 2030. This is based on a white paper's assessment of the needed $\mathrm{CO}_{2}$-certificate price in $2030 \mathrm{in}$ order to achieve the German climate goals $(75 € / \mathrm{kg})$ [96]. Applied to the formerly used example it becomes visible, that including the ecological part of sustainability by internalizing external $\mathrm{CO}_{2}$-emission costs (in DSE), leads to a better performance of the geared concept 3P-3G-DFIG-PC in the used parameterization. Therefore, the authors stress to invest some time to identify the metric which represents the decision-makers' specific preferences in order to reasonably support the design decision.

All previously shown figures depict characteristics derived from historic relationships and correlations. This way the past can help predict how the future might look like. Furthermore, it offers the opportunity to foresee the impact technical changes can have on the overall systems solution favorability. Nevertheless, the authors stress to update all input data before applying this model. Especially for an OEM the ecosystem it operates in needs to be (indirectly) 
addressed in the input data or at least kept in mind when using the model results for decision support.

\section{Conclusions and outlook}

To support the decision making of engineers in the design stage of wind turbine drivetrains an evaluation approach is developed. By using a holistic set of criteria this approach makes it possible to include the entire drivetrain's lifecycle as well as influences of and interdependencies between different components and the underlying trade-offs into the decision. The authors showed that with the help of physicsand empirically-based models a sufficient quantification of the systems characteristics over the lifecycle is possible. A great emphasis has been put on the wide parameterization of the model in order to allow a broad application in an early design stage despite of the lack of data. The default model parameterization is based on literature data. But it can be easily customized with industrial data which will improve the results accuracy.

By utilizing the approach for a drivetrain concept comparison for today's and near future's turbines application it becomes visible how this approach can be used and how valuable its application is. The comparison of a geared and a direct drive concept shows that both concepts score on a comparable level slightly differing in weak and strong wind regimes. Using this approach to examine the design trade-off between investment and operational effort, both concepts under investigation were shown to be more influenced by the investment phase than by the operational, though they differ in their sensitivity. A further analysis varying raw material prices stressed, that parameter variation analysis is needed in order to provide robust decision support. Comparing a macrosocial decision metric to the popular LCOE metric emphasizes, that decision-makers' specific preferences need to be incorporated in order to supply valuable decision support. Finally, the authors stress to update all input data before applying this model.

Future work should increase the sustainability perspective in this approach. It can be broadened with more ecological indicators as well as social aspects. A challenge is to implement it on a high aggregation level, as a lot is unknown in an early design stage. However, currently available Life Cycle Assessment and Social Life Cycle Assessment approaches need detailed information about the products lifecycle. Therefore, some research needs to be done in order to establish a joint interface between these two approaches. In addition, the developed approach should be integrated into virtual product development in order to increase and improve the data basis for the analysis. This way cost drivers in the later stages of the product lifecycle can be avoided. Furthermore, a final product becomes more sustainable in terms of cost and ecology, the earlier a holistic perspective is taken in the development process. The entire framework is furthermore suited for offshore application. To deploy it offshore, transportation needs to be modelled in a different way and a sub-model including the weather conditions has to be incorporated.

Funding Open Access funding enabled and organized by Projekt DEAL.

Open Access This article is licensed under a Creative Commons Attribution 4.0 International License, which permits use, sharing, adaptation, distribution and reproduction in any medium or format, as long as you give appropriate credit to the original author(s) and the source, provide a link to the Creative Commons licence, and indicate if changes were made. The images or other third party material in this article are included in the article's Creative Commons licence, unless indicated otherwise in a credit line to the material. If material is not included in the article's Creative Commons licence and your intended use is not permitted by statutory regulation or exceeds the permitted use, you will need to obtain permission directly from the copyright holder. To view a copy of this licence, visit http://creativecommons.org/licenses/by/4. $0 /$.

\section{References}

1. Bundesnetzagentur für Elektrizität, Gas, Telekommunikation, Post und Eisenbahnen (2020) Genehmigung des Szenariorahmens 2021-2035. https://www.netzausbau.de/SharedDocs/Downloads/ DE/2035/SR/Szenariorahmen_2035_Genehmigung.pdf?_blob= publicationFile. Accessed 6 Feb 2021

2. Bard J, Becker S, Bonin M, Fischer T, Ganal H, Ganal I, Gerhardt N, Hoffmann C, Krautkremer B, Pogacar S, Putcha S, Schmidt D, Schoer R (2019) Energy transition barometer 2018. https://www. herkulesprojekt.de/content/dam/herkulesprojekt/de/documents/ Barometer/2018_B_Barometer_e.pdf. Accessed 25 Mar 2021

3. Liebich A, Fröhlich T, Münter D, Fehrenbach H, Gierigch J, Köppen S, Dünnebeil F, Knörr W, Biemann K (2020) Systemvergleich speicherbarer Energieträger aus erneuerbaren Energien. https://www.umweltbundesamt.de/sites/default/files/medien/479/ publikationen/texte_2020_68_systemvergleich_speicherbarer_ energietraeger_aus_erneuerbaren_energien.pdf. Accessed 29 Mar 2021

4. Bundesnetzagentur für Elektrizität, Gas, Telekommunikation, Post und Eisenbahnen (2021) Beendete Ausschreibungen. https:// www.bundesnetzagentur.de/DE/Sachgebiete/ElektrizitaetundGas/ Unternehmen_Institutionen/Ausschreibungen/Wind_Onshore/ BeendeteAusschreibungen/BeendeteAusschreibungen_node.html. Accessed 6 Feb 2021

5. Fraunhofer-Institut für Solare Energiesysteme (ISE) (2021) Energy Charts Stromproduktion und Börsenstrompreise in Deutschland

6. Stehly T, Beiter P (2019) 2018 Cost of wind energy review. https:// www.nrel.gov/docs/fy20osti/74598.pdf. Accessed 6 Feb 2021

7. Reder MD, Gonzalez E, Melero JJ (2016) Wind turbine failures-Tackling current problems in failure data analysis. J Phys Conf Ser 753:72027. https://doi.org/10.1088/1742-6596/753/7/ 072027

8. Hau E (2017) Windkraftanlagen. Grundlagen. Technik. Einsatz. Wirtschaftlichkeit, 6th edn. Springer, Berlin, Heidelberg, New York

9. Vestas Wind Systems A/S (2017) Life cycle assessment of electricity production from an onshore V112-3.45 MW wind plant. https:// www.vestas.com/ /media/vestas/about/sustainability/pdfs/v1123 
\%2045mw_mk3a_iso_lca_final_31072017.pdf. Accessed 29 Mar 2021

10. Ehrlenspiel K, Kiewert A, Lindemann U, Mörtl M (2014) Kostengünstig Entwickeln und Konstruieren. Kostenmanagement bei der integrierten Produktentwicklung, 7th edn. VDI-Buch. Springer Vieweg, Wiesbaden

11. Polinder H, van der Pijl FFA, de Vilder G-J, Tavner PJ (2006) Comparison of direct-drive and geared generator concepts for wind turbines. IEEE Trans Energy Convers 21(3):725-733. https://doi.org/ 10.1109/TEC.2006.875476

12. Guo Y, Parsons T, Dykes K, King RN (2017) A systems engineering analysis of three-point and four-point wind turbine drivetrain configurations. Wind Energy 20(3):537-550. https://doi.org/10.1002/ we. 2022

13. Carroll J, McDonald A, Dinwoodie I, McMillan D, Revie M, Lazakis I (2017) Availability, operation and maintenance costs of offshore wind turbines with different drive train configurations. Wind Energy 20(2):361-378. https://doi.org/10.1002/we.2011

14. McMillan D, Ault GW (2010) Techno-economic comparison of operational aspects for direct drive and gearbox-driven wind turbines. IEEE Trans Energy Convers 25(1):191-198. https://doi.org/ 10.1109/TEC.2009.2032596

15. Carroll J, McDonald A, McMillan D (2014) Reliability comparison of wind turbines with DFIG and PMG drive trains. IEEE Trans Energy Convers 30(2):663-670. https://doi.org/10.1109/TEC.2014. 2367243

16. Ozturk S, Fthenakis V, Faulstich S (2018) Failure modes, effects and criticality analysis for wind turbines considering climatic regions and comparing geared and direct drive wind turbines. Energies. https://doi.org/10.20944/preprints201807.0602.v1

17. Carroll J, McDonald A, McMillan D, Maples B, Mone C (2015) Cost of energy for offshore wind turbines with different drive train types. In: Proceedings of European Wind Energy Association Annual Event 2015

18. Harzendorf F, Schelenz R, Jacobs G (2017) Lifetime cost evaluation of different wind turbine drive train configurations. In: Wind Energy Science Conference 2017 (Vortrag), Kopenhagen, Dänemark

19. Harzendorf F, Azzam B, Schelenz R, Jacobs G (2018) Manufacturing cost-A critical evaluation criteria for new developments in wind turbine drivetrain technologies. J Phys Conf Ser 1102(1):12024. https://doi.org/10.1088/1742-6596/1102/1/012024

20. Harzendorf F, Schelenz R, Jacobs G (2020) Reducing cost uncertainty in the drivetrain design decision with a focus on the operational phase. Wind Energy Sci Discuss. https://doi.org/10.5194/ wes-2020-37

21. Carroll J, McDonald A, Freuchtwang J, McMillan D (2014) Drivetrain availability in offshore wind turbines. In: Proceedings of European Wind Energy Association Annual Event 2014

22. Carroll J, McDonald A, McMillian D (2015) Offshore cost of energy for DFIG PRC turbines vs. PMG FRC turbines (Bejing, China)

23. Sethuraman L, Maness M, Dykes K (2017) Optimized generator designs for the DTU 10-MW offshore wind turbine using GeneratorSE. In: 35th Wind Energy Symposium https://doi.org/10.2514/6. 2017-0922

24. Sethuraman L, Quick J, Dykes K, Guo Y (2018) Exploring optimization opportunities in four-point suspension wind turbine drivetrains through integrated design approaches. In: 2018 Wind Energy Symposium https://doi.org/10.2514/6.2018-1000

25. Schreiber A, Marx J, Zapp P (2019) Comparative life cycle assessment of electricity generation by different wind turbine types. J Clean Prod 233:561-572. https://doi.org/10.1016/j.jclepro.2019. 06.058

26. Moghadam FK, Nejad AR (2020) Evaluation of PMSG-based drivetrain technologies for 10-MW floating offshore wind turbines: pros and cons in a life cycle perspective. Wind Energy 23(7):1542-1563. https://doi.org/10.1002/we.2499
27. von Nitzsch R (2007) Entscheidungslehre. Wie Menschen entscheiden und wie sie entscheiden sollten, 7th edn. Verlagshaus Mainz, Aachen

28. Bundesministerium für Wirtschaft und Energie (2010) Bundesministerium für Wirtschaft und Energie: Energiekonzept. für eine umweltschonende, zuverlässige und bezahlbare Energieversorgung. https://www.bmwi.de/Redaktion/DE/Downloads/E/energiekonzept2010.pdf? blob $=$ publicationFile $\& v=5$. Accessed 8 June 2020

29. Kost C, Shammugam S, Jülch V, Nguyen H, Schlegl T (2018) Stromgestehungskosten Erneuerbarer Energien. Fraunhofer ISE. https://www.ise.fraunhofer.de/content/dam/ise/de/documents/ publications/studies/DE2018_ISE_Studie_Stromgestehungskosten_ Erneuerbare_Energien.pdf. Accessed 10 Feb 2021

30. Börse Online (2020) CO2 European emission allowances

31. Guo Y, Parsons T, King R, Dykes K (2015) An analytical formulation for sizing and estimating the dimensions and weight of wind turbine hub and drivetrain components, NREL/TP-500063008. National Renewable Energy Laboratory. http://citeseerx. ist.psu.edu/viewdoc/download?doi=10.1.1.738.1437\&rep=rep1\& type=pdf. Zugegriffen: 31 Dez 2020

32. Fingersh L, Hand M, Laxson A (2006) Wind turbine design cost and scaling model. NREL. https://www.nrel.gov/docs/fy07osti/40566. pdf. Zugegriffen: 31 Dez 2020

33. Eisen Schmitt (2008) Lagerpreisliste für den Verkauf von Stahl. https://www.eisen-schmitt.de/fileadmin/user_upload/Downloads/ Lagerpreisliste2008.pdf. Accessed 4 July 2019

34. Dünnewald Stahlhandel (2008) Lagerpreisliste für den Verkauf von Stahl. https://www.duennewald.de/files/LagerpreislisteFlachprodukte.pdf. Accessed 4 July 2019

35. Papadopoulos I (2010) Comparative analysis of electricity generating technologies with regards to environmental burdens. Doktorarbeit

36. KMD Group (2019) Metal prices Germany

37. Sethuraman L, Dykes K (2017) GeneratorSE-A sizing tool for variable-speed wind turbine generators, NREL/TP-5000-66462. National Renewable Energy Laboratory, Golden, Colorado. https:// www.nrel.gov/docs/fy17osti/66462.pdf. Accessed 29 Mar 2021

38. Argus Metals (2018) Argus metal prices. Global market prices, news and analysis, 18-20. https://www.argusmedia.com/en/metals. Accessed 4 July 2019

39. LME-The London Metal Exchange (2019) Homepage der the London Metal Exchange (LME)

40. Thomas Eisen Werkstoffhandel (2019) Lagerprogrammübersicht

41. Mercateo (2019) ARCANOL-LOAD400-400G Arcanol-Wälzlagerfett. http://www.mercateo.com/p/2302-11482/ARCANOL_ LOAD400_400G_Arcanol_Waelzlagerfett.html. Accessed 20 June 2020

42. Liaoning Borui Machinery CO. LTD (Dandong Foundry) (2019) Cast iron prices per pound, kilogram or ton

43. Statistisches Bundesamt (2019) GENESIS-Online Datenbank. https://www-genesis.destatis.de/genesis/online. Accessed 29 Mar 2021

44. Suter P, Frischknecht R (1996) Ökoinventare von Energiesystemen - Grundlagen für den ökologischen Vergleich von Energiesystemen und den Einbezug von Energiesystemen in Ökobilanzen für die Schweiz, Zürich

45. Fachvereinigung Betonrohre und Stahlbetonrohre e.V. (FBS) Rohrwerkstoffauswahl - ein Vergleich. Umweltverträglichkeit/ Ökobilanz von Abwasserkanalrohren. Zugegriffen: 31 Dez 2020

46. Walachowicz F, March A, Fiedler S, Buchert M, Sutter J, Merz C (2014) Recycling von Elektromotoren - MORE. Teilprojekt: Ökobilanz der Recyclingverfahren. Siemens AG; Öko-Institut e. V. https://www.oeko.de/fileadmin/oekodoc/MORE-LCA-Endbericht. pdf. Accessed 27 Mar 2021

47. Worldsteel Association (2018) Life cycle inventory study-2018 data release. https://www.worldsteel.org/en/dam/jcr:04f8a180- 
1406-4f5c-93ca-70f1ba7de5d4/2018\%2520LCI\%2520Study \%2520Report\%2520vfinal.pdf. Accessed 27 Mar 2021

48. Deutsches Kupferinstitut - Copper Alliance (2018) Blick über den Horizont - Ganzheitliche Umweltprofile von Kupferprodukten, Düsseldorf. http://www.copperalliance.de/uploads/2018/06/life_ cycle_brochure_high_res_de_x3-pdf.pdf. Accessed 15 Sept 2019

49. European Aluminium Association (2018) Environmental profile report: life-cycle inventory data for aluminium production and transformation processes in Europe, Brüssel

50. Hering E (2014) Kalkulation für Ingenieure. Springer, Wiesbaden

51. Geuder M (2004) Energetische Bewertung von Windkraftanlagen. Diplomarbeit. https://www.bastgen.de/schule/physik/10/KEA/ Studie_FH-W\%25FCrzburg_EnergBewertung.pdf. Accessed 28 Mar 2021

52. Holtappels J, Steinfeld M (2017) Transport und Krantechnik in der Windenergie (Interview), Köln

53. Klodt T, Steinfeld M (2017) Transport und Montage von Windkraftanlagen (Interview), Köln

54. Liebherr-Werk Ehingen GmbH (2016) Liebherr-Spitzentechnik Krane für die Windkraft

55. Barenhorst F, Serowy S, Andrei C, Schelenz R, Jacobs G, Hameyer K (2016) New drive train concept with multiple high speed generator. J Phys Conf Ser 753:112001. https://doi.org/10.1088/1742-6596/ 753/11/112001

56. Fuglsang P, Thomes K (1998) Cost optimization for wind turbines for large-scale offshore wind farms

57. Krohn S, Morthorst P-E, Awerbuch S (2009) The economics of wind energy - A report by the European wind energy association. EWEA. http://www.ewea.org/fileadmin/files/library/publications/ reports/Economics_of_Wind_Energy.pdf. Accessed 28 Mar 2021

58. Burton T (2011) Wind energy handbook, 2nd edn. John Wiley \& Sons, Ltd, Chichester

59. Megavind (2012) Strategy for wind turbine components and subsystems. Report from Megavind. https://ens.dk/sites/ens.dk/files/ Forskning_og_udvikling/strategy_for_wind_turbine_components_ and_subsystems.2012.pdf. Accessed 27 June 2018

60. Kooijman HJT, de Noord M, Volkers CH, Machielse LAH, Hagg F, Eecen PJ, Pierik JTG, Herman SA (2018) Cost and potential of offshore wind energy on the dutch part of the north sea. http:// www.olino.org/blog/nl/wp-content/uploads/2008/articles/cost and_potential_of_offshore_wind_energy_on_the_dutch_part_of_ the_North_Sea.pdf. Accessed 20 Dec 2018

61. Poore R, Lettenmaier T (2003) WindPACT advanced wind turbine drive train designs study. Alternative design study report, NREL/SR-500-33196. National Renewable Energy Laboratory, Golden, Colorado. https://www.nrel.gov/docs/fy03osti/33196.pdf. Zugegriffen: 31 Dez 2020

62. Nitsch J, Pregger T, Scholz Y, Naegler T, Sterner M, Gerhardt N, von Oehsen A, Pape C, Saint-Drenan Y-S, Wenzel B (2010) Langfristszenarien und Strategien für den Ausbau der erneuerbaren Energien in Deutschland bei Berücksichtigung der Entwicklung in Europa und global - Leitstudie 2010. https://elib.dlr.de/69139/1/ Leitstudie_2010.pdf. Accessed 29 Mar 2021

63. Mone C, Smith A, Maples B, Hand M (2013) 2013 cost of wind energy review. https://www.nrel.gov/docs/fy15osti/63267.pdf. Accessed 29 Mar 2021

64. Chaviaropoulos P, Natarajan A (2014) Definition of performance indicators and target values

65. McKenna R, Hollnaicher S, Fichtner W (2014) Cost-potential curves for onshore wind energy: A high-resolution analysis for Germany. Appl Energy 115:103-115. https://doi.org/10.1016/j. apenergy.2013.10.030

66. Mone C, Stehly T, Maples B, Settle E (2015) 2014 cost of wind energy review. https://www.nrel.gov/docs/fy16osti/64281.pdf. Accessed 26 June 2018
67. International Renewable Energy Agency (IRENA) (2018) Renewable power generation costs in 2017. International Renewable Energy Agency (IRENA). https://www.irena.org/-/media/ Files/IRENA/Agency/Publication/2018/Jan/IRENA_2017_Power_ Costs_2018.pdf. Accessed 20 Dec 2018

68. Fraunhofer Institut für Windenergie und Energiesystemtechnik (IWES) (2018) Windmonitor

69. Reichenberg L, Hedenus F, Odenberger M, Johnsson F (2018) The marginal system LCOE of variable renewables-Evaluating high penetration levels of wind and solar in Europe. Energy 152:914-924. https://doi.org/10.1016/j.energy.2018.02.061

70. Al-Behadili SH, El-Osta WB (2015) Life cycle assessment of Dernah (Libya) wind farm. Renew Energy 83:1227-1233. https://doi. org/10.1016/j.renene.2015.05.041

71. Bonou A, Laurent A, Olsen SI (2016) Life cycle assessment of onshore and offshore wind energy from theory to application. Appl Energy 180:327-337. https://doi.org/10.1016/j.apenergy.2016.07. 058

72. Ortegon K, Nies LF, Sutherland JW (2013) Preparing for end of service life of wind turbines. J Clean Prod 39:191-199. https://doi. org/10.1016/j.jclepro.2012.08.022

73. Guezuraga B, Zauner R, Pölz W (2012) Life cycle assessment of two different $2 \mathrm{MW}$ class wind turbines. Renew Energy 37(1):37-44. https://doi.org/10.1016/j.renene.2011.05.008

74. Engels W, Obdam T, Savenije F (2009) Current developments in wind-2009 going to great lengths to improve wind energy. ECNE-96

75. Eurelectric (2010) Power choices. Pathways to carbon-neutral electricity in Europe by 2050

76. Esken A, Höller S, Luhmann H-J, Pietzner K, Vallenti D, Viehbahn P, Dietrich L, Nitsch J (2010) Regenerative Energien (RE) im Vergleich mit CO2-Abtrennung und -Ablagerung (CCS) - Update und Erweiterung der RECCS-Studie 0329967/07000285 (Wuppertaler Institut für Klima, Umwelt, Energie $\mathrm{GmbH}$ )

77. Fraunhofer-Institut für Solare Energiesysteme (ISE) (2010) Stromgestehungskosten Erneuerbarer Energien. https://www.ise. fraunhofer.de/de/veroeffentlichungen/studien/studie-

stromgestehungskosten-erneuerbare-energien.html. Accessed 28 Mar 2021

78. Buchholz W, Frank J, Karl HD, Pfeiffer J, Pittel K, Triebswetter U, Habermach J, Mauch W, Staudach T (2012) Die Zukunft der Energiemärkte - Ökonomische Analyse und Bewertung von Potenzialen und Handlungsmöglichkeiten. Ifo Forschungsberichte. Forschungsstelle für Energiewirtschaft, München. https://www.ifo. de/DocDL/ifo_Forschungsbericht_57.pdf. Accessed 27 Mar 2021

79. Fraunhofer-Institut für Solare Energiesysteme (ISE) (2012) Stromgestehungskosten Erneuerbare Energien. https://www.ise. fraunhofer.de/de/veroeffentlichungen/studien/studiestromgestehungskosten-erneuerbare-energien.html. Accessed 28 Mar 2021

80. Peter F, Krampe L, Zeigenhaben I, Prognos (eds) (2013) Entwicklung von Stromproduktionskosten - Die Rolle von Freiflächen-Solarkraftwerken in der Energiewende

81. Fraunhofer-Institut für Solare Energiesysteme (ISE) (2013) Stromgestehungskosten Erneuerbarer Energien. https://www.ise.fraunhofer. $\mathrm{de} / \mathrm{de} /$ veroeffentlichungen/studien/studie-stromgestehungskostenerneuerbare-energien.html. Accessed 28 Mar 2021

82. Leipziger Institut für Energie GmbH (2014) Vorhaben IIe Stromerzeugung aus Windenergie. Wissenschaftlicher Bericht. https:// www.swr.de/-/id=14144868/property=download/nid=7446566/ 1p1ismv/index.pdf. Accessed 29 Mar 2021

83. Wallasch A, Lüers S, Rehfeld K (2013) Kostensituation der Windenergie an Land in Deutschland. https://publikationen. windindustrie-in-deutschland.de/kostensituation-der-windenergiean-land/54436234/2. Accessed 29 Mar 2021

84. Wiser R, Bolinger M (2014) 2014 Wind technologies market report 
85. Valpy B, English P, Martinez A, Simonot E (2014) Future renewable energy costs: onshore wind. How technology innovation is anticipated to reduce the cost of energy from European onshore wind farms. KIC InnoEnergy. https://eit.europa.eu/sites/default/ files/KIC_IE_OnshoreWind_anticipated_innovations_impact.pdf. Accessed 3 Dec 2018

86. Wiser R, Karen J, Seel J, Baker E, Hand M, Lantz E, Smith A Forecasting wind energy cost and cost drivers. The views of the world's leading experts. https://emp.lbl.gov/publications/forecasting-windenergy-costs-and. Accessed 27 Mar 2021

87. Shafiee M, Brennan F, Espinosa IA (2016) A parametric whole life cost model for offshore wind farms. Int J Life Cycle Assess 21(7):961-975. https://doi.org/10.1007/s11367-016-1075-z

88. Hahn B (2017) Technologiebericht 1.6 Windenergie mit Exkurs Meeresenergie innerhalb des Forschungsprojektes TF-Energiewende. https://epub.wupperinst.org/frontdoor/deliver/index/docId/7046/ file/7046_Windenergie.pdf. Accessed 20 Dec 2018

89. Wiser R, Bolinger M (2018) 2017 Wind technologies market report

90. Kost D, Schlegl T (2018) Stromgestehungskosten erneuerbare Energien

91. Deutscher Bundestag (2017) Gesetz für den Ausbau erneuerbarer Energie (Erneuerbare-Energien-Gesetz - EEG 2017). EEG 2017

92. Wallasch A, Luers S, Rehfeld K (2018) Vorbereitung und Begleitung bei der Erstellung eines Erfahrungsberichts gemäß $§ 97$ Erneuerbare-Energien-Gesetz.

https://www.windguard.de/ veroeffentlichungen.html?file=files/cto_layout/img/unternehmen/ veroeffentlichungen/2019/Endbericht $\% 202019 \% 20 \% \mathrm{E} 2 \% 80 \% 93$ \%20Erfahrungsbericht\%20gem\%C3\%A4\%C3\%9F\%20\%C2\%A7 $\% 2097 \% 20$ EEG\%20-\%20Wind\%20an\%20Land.pdf. Accessed 24 Apr 2020

93. Vestas Wind Systems A/S (2020) Vestas annual report 2020. https:// mb.cision.com/Main/18886/3283502/1370563.pdf. Accessed 14 Mar 2021

94. Hernandez C (2017) JRC wind energy status report 2016 edition

95. Vestas Wind Systems A/S (2021) EnVentus platform. https:// www.vestas.com/en/products/enventus_platform/v150-6_0_mw. Accessed 14 Apr 2021

96. Nordes SE The N149/5.X. https://www.nordex-online.com/en/ product/n149-5-x/. Accessed 14 Apr 2021

97. GE Renewables (2021) Cypress onshore wind turbine platform. https://www.ge.com/renewableenergy/wind-energy/onshore-wind/ cypress-platform. Accessed 14 Apr 2021

98. Siemens Gamesa (2021) Wind turbine - SG 5.8-155. https://www. siemensgamesa.com/en-int/products-and-services/onshore/windturbine-sg-5-8-155. Accessed 14 Apr 2021

99. neodym-preis.de (2021) Neodym Preis

100. Magnethandel.de (2021) Price trend noedymium magnet

101. Institut für seltene Erden und strategische Metalle (2021) Preise für Neodym 